\title{
RETRACTED ARTICLE: DDB1 and Cul4 are necessary for gene silencing and heterochromatin formation at pericentromeric regions in Neurospora
}

\author{
Yingqiong $\mathrm{Cao}^{1}$, Jicheng $\mathrm{Wei}^{2}$, Silu Yang ${ }^{1}$, Jinquan Sun ${ }^{1}$, Hui Xu', Ying Wang ${ }^{1}$, Yuanbiao Zhao ${ }^{1 凶}$, \\ Qun He ${ }^{1 / \mathbb{M}}$ \\ ${ }^{1}$ State Key Laboratory of Agrobiotechnology, College of Biological Sciences, China Agricultural University, Beijing 100193, \\ China \\ 2 Biology Department, Mudanjiang Teachers College, Mudanjiang 157011, China \\ $\bowtie$ Correspondence: bossbiao@gmail.com (Y. Zhao), qunhe@cau.edu.cn (Q. He) \\ Received March 1, 2014 Accepted March 1, 2014
}

This article has been retracted by the editorial office of Journal Protein \& Cell as Prof. Danesh Moazed found data manipulation in the article. The Editor-in-Chief agreed to the retraction.

\section{OPEN ACCESS}

This article is distributed under the terms of the Creative Commons Attribution License which permits any use, distribution, and reproduction in any medium, provided the original author(s) and the source are credited.

This article has been retracted by the editorial office of Journal Protein \& Cell as Prof. Danesh Moazed found data manipulation in the article. The Editor-in-Chief agreed to the retraction. 